Background: Hydrogen peroxide $\left(\mathrm{H}_{2} \mathrm{O}_{2}\right)$ in exhaled air condensate is elevated in inflammatory disorders of the lower respiratory tract. It is unknown whether viral colds contribute to exhaled $\mathrm{H}_{2} \mathrm{O}_{2}$.

Aim: To assess exhaled $\mathrm{H}_{2} \mathrm{O}_{2}$ during and after a common cold.

Metbods: We examined $\mathrm{H}_{2} \mathrm{O}_{2}$ in the breath condensate of 20 normal subjects with acute symptoms of a common cold and after recovery 2 weeks later and, similarly, in 10 subjects without infection. $\mathrm{H}_{2} \mathrm{O}_{2}$ was measured with a fluorimetric assay.

Results: At the time of infection exhaled $\mathrm{H}_{2} \mathrm{O}_{2}$ (median, ranges) was $0.20 \mu \mathrm{M}(0.03-1.2 \mu \mathrm{M})$, and this decreased to $0.09 \mu \mathrm{M}(<0.01-0.40 \mu \mathrm{M})$ after recovery $(p=0.006)$. There was no significant difference in lung function (forced vital capacity and forced expiratory volume in $1 \mathrm{sec}$ ) during and after colds. In the controls, exhaled $\mathrm{H}_{2} \mathrm{O}_{2}$ did not change over a 2-week period.

Conclusions: $\mathrm{H}_{2} \mathrm{O}_{2}$ in exhaled air condensate is elevated during a common cold, and returns to normal within 2 weeks of recovery in healthy subjects. Hence, symptomatic upper respiratory tract infection may act as a confounder in studies of $\mathrm{H}_{2} \mathrm{O}_{2}$ as a marker of chronic lower airway inflammation.

Key words: Exhaled air condensate, Hydrogen peroxide, Common cold

\section{Hydrogen peroxide in breath condensate during a common cold}

\author{
Rijn Q. Jöbsis ${ }^{1,2}$, Susanne L. Schelleken $\mathbf{s}^{1}$, \\ Anoeska Fakkel-Kroesbergen ${ }^{1}$, \\ Rolien H. C. Raatgeep ${ }^{1}$ and Johan C. de Jongste ${ }^{1, C A}$
}

${ }^{1}$ Department of Paediatrics, Division of Paediatric Respiratory Medicine, Erasmus University Medical Center/Sophia Children's Hospital, PO Box 2060, 3000 CB Rotterdam, The Netherlands; and ${ }^{2}$ Department of Paediatrics, University Hospital Maastricht, PO Box 5800, 6202 AZ Maastricht, The Netherlands

\footnotetext{
${ }^{\mathrm{CA}}$ Corresponding Author

Tel: +31 104636263

Fax: +31 104636801

E-mail: dejongste@lons.azr.nl
}

\section{Introduction}

Exhaled air condensate can be collected with minimal risk and inconvenience, and provides a means for obtaining samples from the lower respiratory tract. ${ }^{1,2}$ Hydrogen peroxide $\left(\mathrm{H}_{2} \mathrm{O}_{2}\right)$ in exhaled air condensate is a potential marker of airway inflammation. ${ }^{1,3}$ An increased content of $\mathrm{H}_{2} \mathrm{O}_{2}$ has been described in exhaled air of patients with various inflammatory lung disorders. ${ }^{1,4-7}$ Therefore, $\mathrm{H}_{2} \mathrm{O}_{2}$ in breath condensate may be a simple and non-invasive marker to diagnose and monitor chronic airway inflammation in the lower respiratory tract. Little is known about the effect of upper airway inflammation on exhaled $\mathrm{H}_{2} \mathrm{O}_{2}$, and exhaled air condensate could be potentially confounded by upper airway infection. The aim of this study was to assess whether a common cold affects orally exhaled $\mathrm{H}_{2} \mathrm{O}_{2}$ in otherwise healthy subjects.

\section{Methods}

\section{Study population}

We recruited by advertisement 20 normal subjects with acute $(<48 \mathrm{~h})$ symptoms of a common cold: stuffy or running nose, sneezing, sore throat, with or without fever. Similarly, we recruited 10 healthy agematched control subjects without respiratory symptoms. All were lifelong non-smokers, had no history of allergy, sinusitis and respiratory or cardiovascular disease, had no symptoms of asthma or eczema, and used no medication. Control subjects had no symptoms of respiratory tract infection in the 4 weeks before, or during, the measurements. Characteristics are presented in Table 1 . The study was approved by the Medical Ethical Committee of the Erasmus University Medical Centre.

\section{Collection of breath condensate}

Condensate was collected twice in all subjects: at inclusion, and 2 weeks later when symptoms had dissapeared. The subjects breathed through a mouthpiece and a two-way non-rebreathing valve (Rudolph, Kansas City, MO, USA) that also served as as saliva trap. They were asked to breath at a normal frequency and tidal volume, wearing a nose clip. Exhaled air condensate was obtained by passing expired air through a $50 \mathrm{~cm}$ long, double-jacketed, wide bore glass tube cooled to a temperature of $0^{\circ} \mathrm{C}$, by means of counter-current circulating ice water. The resulting condensate was collected on ice, frozen immediately at $-20^{\circ} \mathrm{C}$ and kept in the dark until analysis. 
Table 1. Patient characteristics, lung function and $\mathrm{H}_{2} \mathrm{O}_{2}$ values

\begin{tabular}{|c|c|c|c|c|}
\hline \multirow{3}{*}{$\begin{array}{l}n \\
\text { Sex (male/female) } \\
\text { Age (years) [median (range)] }\end{array}$} & \multicolumn{2}{|c|}{ Subjects with a common cold } & \multicolumn{2}{|c|}{ Controls } \\
\hline & 25.6 & $\begin{array}{l}0 \\
13 \\
.8-51.2)\end{array}$ & 26.0( & $\begin{array}{l}0 \\
5 \\
.1-48.4)\end{array}$ \\
\hline & $\begin{array}{c}t=0 \text { weeks } \\
(\text { symptomatic) }\end{array}$ & $\begin{array}{l}t=2 \text { weeks } \\
\text { (recovered) }\end{array}$ & $t=0$ weeks & $t=2$ weeks \\
\hline $\begin{array}{l}\mathrm{FVC}(\% \text { predicted) [mean (SEM)] } \\
\mathrm{FEV}_{1}(\% \text { predicted) [mean (SEM)] } \\
\mathrm{H}_{2} \mathrm{O}_{2}(\mu \mathrm{M}) \text { [median (range)] }\end{array}$ & $\begin{array}{l}108(2) \\
106(2) \\
0.20(0.03-1.20)\end{array}$ & $\begin{array}{l}109(2) \\
107(2) \\
0.09(<0.01-0.40)\end{array}$ & $\begin{array}{l}101(3) \\
101(3) \\
0.10(0.01-0.30)\end{array}$ & $\begin{aligned} 98 & (3) \\
100 & (3) \\
0.08 & (<0.01-0.25)\end{aligned}$ \\
\hline
\end{tabular}

\section{$\mathrm{H}_{2} \mathrm{O}_{2}$ measurement}

The concentration of $\mathrm{H}_{2} \mathrm{O}_{2}$ in exhaled air condensate was measured in duplicate with a fluorimetric assay based on the reaction of $\mathrm{H}_{2} \mathrm{O}_{2}$ with horseradish peroxidase to form a compound that oxidizes $p$-hydroxyphenylacetic acid to a fluorescent product. Fluorescence of the condensate and of standard solutions of $\mathrm{H}_{2} \mathrm{O}_{2}$ were quantified fluorimetrically, as described in detail previously. ${ }^{1,8}$ Concentrations of $\mathrm{H}_{2} \mathrm{O}_{2}$ in the condensate were obtained by linear interpolation of a standard curve. The lower limit of $\mathrm{H}_{2} \mathrm{O}_{2}$ detection was $0.01 \mu \mathrm{M}$. The equipment was designed to avoid contamination of the condensate with saliva, a source of $\mathrm{H}_{2} \mathrm{O}_{2}$. We excluded saliva contamination, as described previously, ${ }^{9}$ by measuring amylase in all condensate samples.

\section{Lung function}

All subjects performed flow-volume measurements in triplicate immediately after collection of the condensate, using a Lilly-type pneumotachograph (Masterlab Jaeger, Würzberg, Germany). Results of forced vital capacity (FVC) and forced expiratory volume in $1 \mathrm{sec}\left(\mathrm{FEV}_{1}\right)$ were expressed as percentage predicted.

\section{Data analysis}

$\mathrm{H}_{2} \mathrm{O}_{2}$ concentrations are expressed as median and range; data were log-normally distributed. Hence, parametric tests were carried out on log-transformed data. The difference, over a 2-week interval, in $\mathrm{H}_{2} \mathrm{O}_{2}$ levels and lung function parameters within each group was assessed with Student's paired $t$-tests, whereas differences between groups were tested with unpaired $t$-tests. Two-tailed $p<0.05$ was considered significant.

\section{Results}

All subjects performed the condensate collections without difficulty. In none of the 60 collected condensate samples was amylase detected, which excludes contamination with saliva. In subjects with colds, $\mathrm{H}_{2} \mathrm{O}_{2}$ levels (median, ranges) were $0.20 \mu \mathrm{M}$ $(0.03-1.20 \mu \mathrm{M})$. After recovery, $\mathrm{H}_{2} \mathrm{O}_{2}$ was significantly lower at $0.09 \mu \mathrm{M}(<0.01-0.40 \mu \mathrm{M})(p=0.006)$. In the control group, the exhaled $\mathrm{H}_{2} \mathrm{O}_{2}$ levels were stable over a 2-week period: $0.10 \mu \mathrm{M}(0.01-0.30 \mu \mathrm{M})$ and $0.08 \mu \mathrm{M}(<0.01-0.25 \mu \mathrm{M})$ (not significant). Initial values of subjects with and without colds were not significantly different. Group data are summarized in Table 1, and individual data are shown in Fig. 1.

There was no significant change in FVC and $\mathrm{FEV}_{1}$ during and after upper respiratory tract infection (mean, $(\mathrm{SEM})$ ): $\mathrm{FVC}=108 \%(8 \%), \mathrm{FEV}_{1}=106 \%(9 \%)$ compared with FVC $109 \%(8 \%), \mathrm{FEV}_{1} 107 \%$ (9\%) after 2 weeks. Likewise, lung function was stable in all controls. There was no correlation between exhaled $\mathrm{H}_{2} \mathrm{O}_{2}$ levels and lung function in both groups.

\section{Discussion}

We found that a common cold is associated with transiently elevated levels of exhaled $\mathrm{H}_{2} \mathrm{O}_{2}$ in nonsmoking normal subjects. After recovery, 2 weeks later, exhaled $\mathrm{H}_{2} \mathrm{O}_{2}$ had decreased to values similar to those of an age-matched healthy control group. Lung function data in subjects with upper respiratory tract infection showed no significant change. These findings suggest that upper respiratory tract inflammation during a common cold increases production of peroxide in the respiratory tract, and may thus act as confounder in studies using exhaled $\mathrm{H}_{2} \mathrm{O}_{2}$ as a marker of chronic lower airway inflammation, especially asthma.

We based the diagnosis of a common cold on typical clinical symptoms. We did not attempt to identify respiratory viruses by means of culture, serology or other tests. However, the nature and time course of upper airway symptoms and the season of the year in which this study took place (autumn) make it likely that respiratory viruses were involved. The elevated exhaled $\mathrm{H}_{2} \mathrm{O}_{2}$ levels during a common cold in this study were below levels reported 
(A)

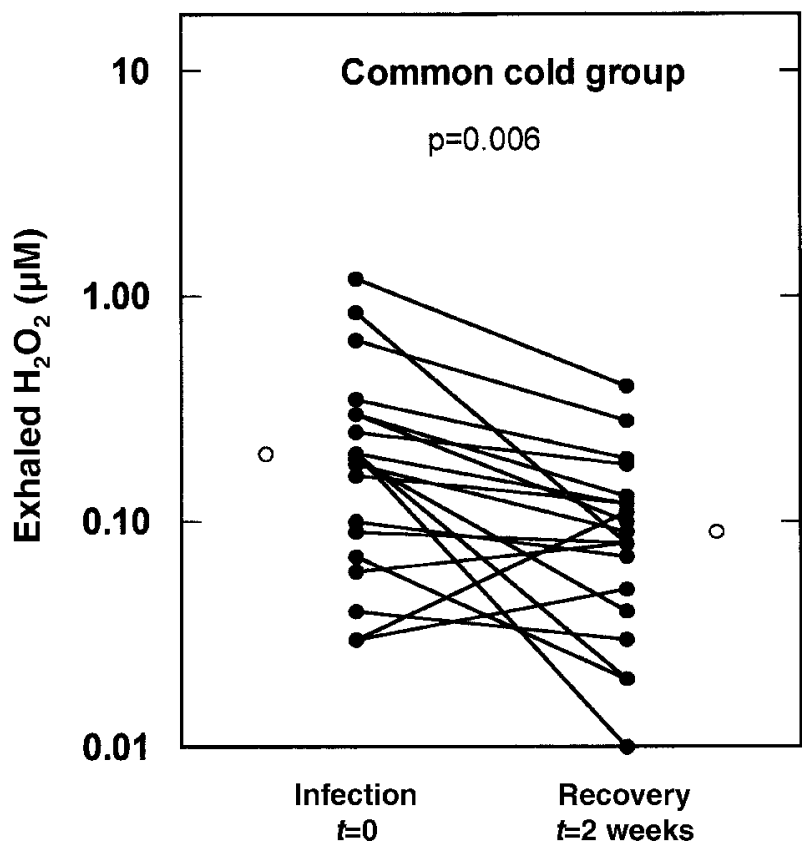

(B)

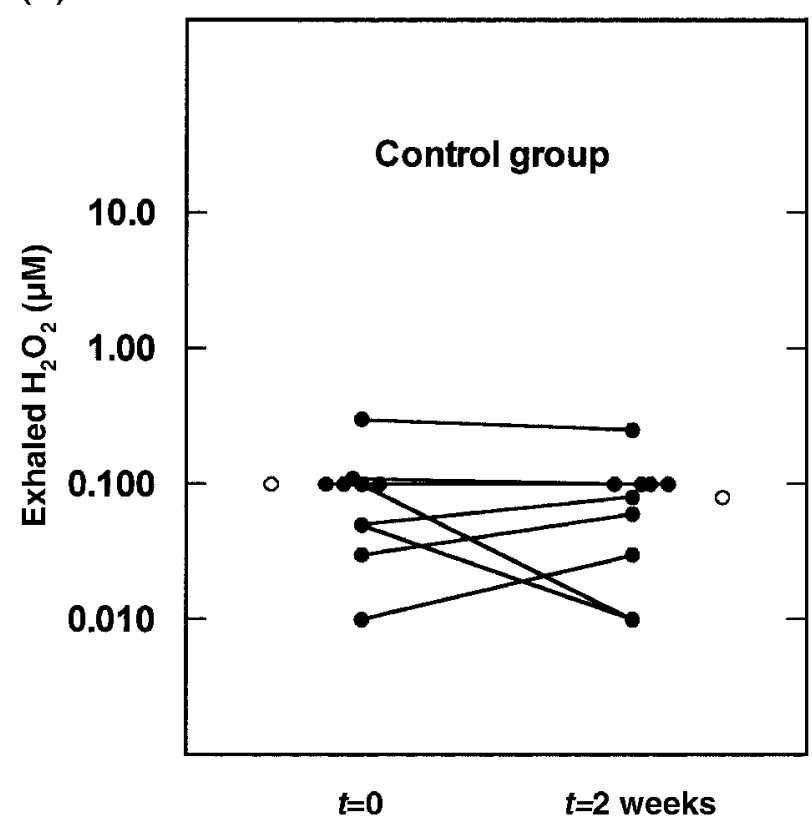

FIG. 1. Concentrations of $\mathrm{H}_{2} \mathrm{O}_{2}$ in exhaled air condensate during and 2 weeks after a common cold (A) and, similarly, in controls without infection (B). Closed symbols represent individual values, open symbols are medians. The difference between $\mathrm{H}_{2} \mathrm{O}_{2}$ values during and after colds is significant $(p=0.006)$.

previously by different groups in stable steroid-naive asthmatic children and adults, ${ }^{1,3}$ and were in the same range as those in stable chronic obstructive pulmonary disease patients. ${ }^{6}$ Our baseline values are in the same range as those reported previously for normals. ${ }^{9}$

The source of increased $\mathrm{H}_{2} \mathrm{O}_{2}$ in breath condensate during a common cold is as yet unclear. We excluded saliva contamination and air was collected by mouth breathing with the use of a nose clip, which should prevent or limit contamination with nasal air. Therefore, it is more likely that increased $\mathrm{H}_{2} \mathrm{O}_{2}$ was due to oral, pharyngeal or lower airway inflammation. However, we have no positive indication that the lower airways were involved in the infectious process, as there was no significant change in $\mathrm{FVC}$ and $\mathrm{FEV}_{1}$ or flow volume curve configuration during and after a common cold. Furthermore, none of the subjects of the infected group had symptoms suggestive of lower airway inflammation, such as bringing up sputum or dyspnea. Chest auscultation was always normal. However, subclinical lower airway inflammation has been documented in viral upper respiratory tract infections and may go without significant changes in lung function. ${ }^{10-12}$ Invasive studies would be necessary to find out if the observed change in exhaled $\mathrm{H}_{2} \mathrm{O}_{2}$ actually reflected subclinical lower airway inflammation or was due to contamination from the upper airways.

What are the implications of our findings? When using exhaled $\mathrm{H}_{2} \mathrm{O}_{2}$ as a marker of chronic airway inflammation in inflammatory lower airway disorders, an intercurrent symptomatic upper respiratory tract infection will probably contribute to exhaled peroxide levels and thereby act as a confounder. To avoid this, exhaled $\mathrm{H}_{2} \mathrm{O}_{2}$ measurements for monitoring lower airway inflammation should not take place during a common cold. An interval of 2 weeks appears prudent, at least in normals.

In conclusion, we found that $\mathrm{H}_{2} \mathrm{O}_{2}$ concentration in exhaled air condensate is significantly elevated during common cold, and returns to normal within 2 weeks. Thus, when evaluating exhaled $\mathrm{H}_{2} \mathrm{O}_{2}$ as a marker of lower airway inflammation, measurements during or soon after colds should be avoided.

ACKNOWLEDGEMENTS. This study was supported by grant 94.14 from the Netherlands Asthma Fund.

\section{References}

1. Jöbsis Q, Raatgeep HC, Hermans PWM, de Jongste JC. Hydrogen peroxide in exhaled air is increased in stable asthmatic children. Eur Respir J 1997; 10: 519-521.

2. Scheideler L, Manke H-G, Schwulera U, Inacker O, Hämmerle H Detection of nonvolatile macromolecules in breath: a possible diagnostic tool? Am Rev Respir Dis 1993; 148: 778-784.

3. Horváth I, Donnelly LE, Kiss A, Kharitonov SA, Lim S, Chung KF, Barnes PJ. Combined use of exhaled hydrogen peroxide and nitric oxide in monitoring asthma. Am J Respir Crit Care Med 1998; 158 1042-1046.

4. Dohlman AW, Black HR, Royall JA. Expired breath hydrogen peroxide is a marker of acute airway inflammation in pediatric patients with asthma Am Rev Respir Dis 1993; 148: 955-960.

5. Kietzmann D, Kahl R, Müller M, Burchardi H, Kettler D. Hydrogen peroxide in expired breath condensate of patients with acute respiratory failure and with ARDS. Intensive Care Med 1993; 19: 78-81. 
6. Dekhuijzen PNR, Aben KKH, Dekker I, Aarts LPHJ, Wielders PLML, Van Herwaarden CLA, Bast A. Increased exhalation of hydrogen peroxide in patients with stable and unstable chronic obstructive pulmonary disease. Am J Respir Crit Care Med 1996; 154: 813-816.

7. Jöbsis Q, Raatgeep HC, Schellekens SL, Kroesbergen A, Hop WCJ, de Jongste JC. Hydrogen peroxide and nitric oxide in exhaled air of children with cystic fibrosis during antibiotic treatment. Eur Respir J 2000; 16 : 95-100.

8. Hyslop PA, Sklar LA. A quantitative fluorimetric assay for the determination of oxidant production by polymorphonuclear leukocytes: its use in the simultaneous fluorimetric assay of cellular activation processes. Anal Biochem 1984; 141: 280-286.

9. Jöbsis Q, Raatgeep HC, Schellekens SL, Hop WCJ, Hermans PWM, de Jongste JC. Hydrogen peroxide in exhaled air of healthy children: reference values. Eur Respir J 1998; 12: 483-485.
10. Frenkel DJ, Bardin PG, Sanderson G, Lampe F, Johnson SL, Holgate ST Lower airway inflammation during rhinovirus colds in normal and in asthmatic subjects. Am J Respir Crit Care Med 1995; 151: 879-886.

11. Corne JM, Holgate ST. Mechanisms of virus induced exacerbations of asthma. Thorax 1997; 52: 380-389.

12. Grünberg K, Smits HH, Timmers MC, et al. Experimental rhinovirus 16 infection. Effects on cell differentials and soluble markers in sputum in asthmatic subjects. Am J Respir Crit Care Med 1997; 156: 609-616.

\section{Received 17 August 2000}

Accepted 13 September 2001 


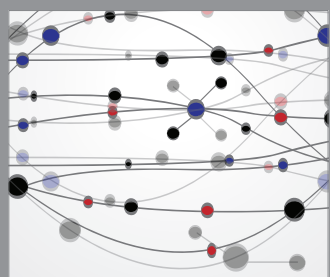

The Scientific World Journal
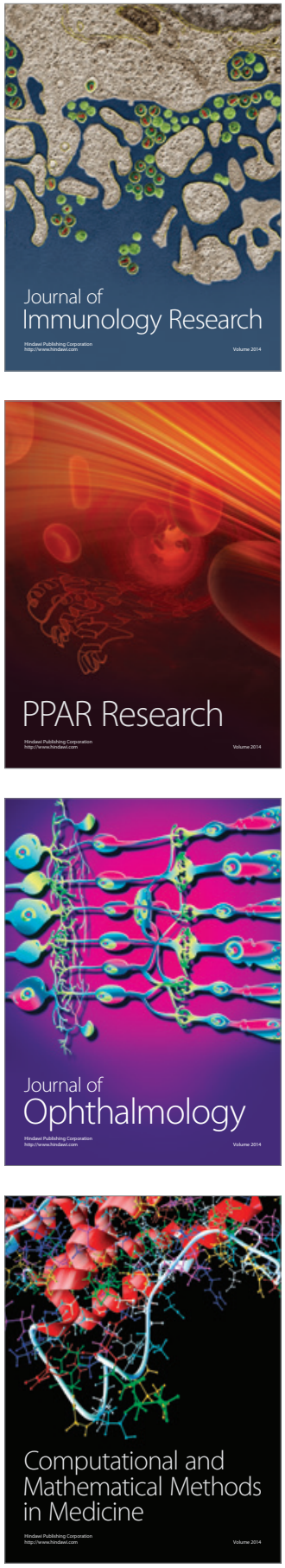

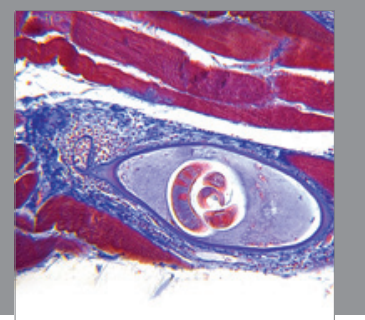

Gastroenterology

Research and Practice
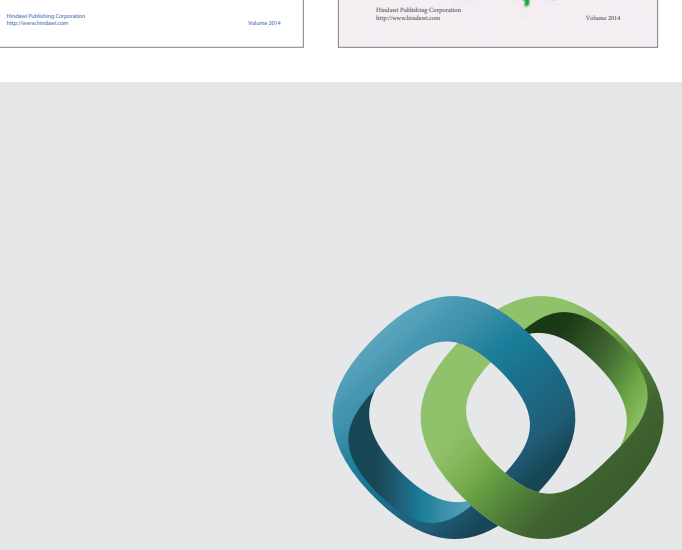

\section{Hindawi}

Submit your manuscripts at

http://www.hindawi.com
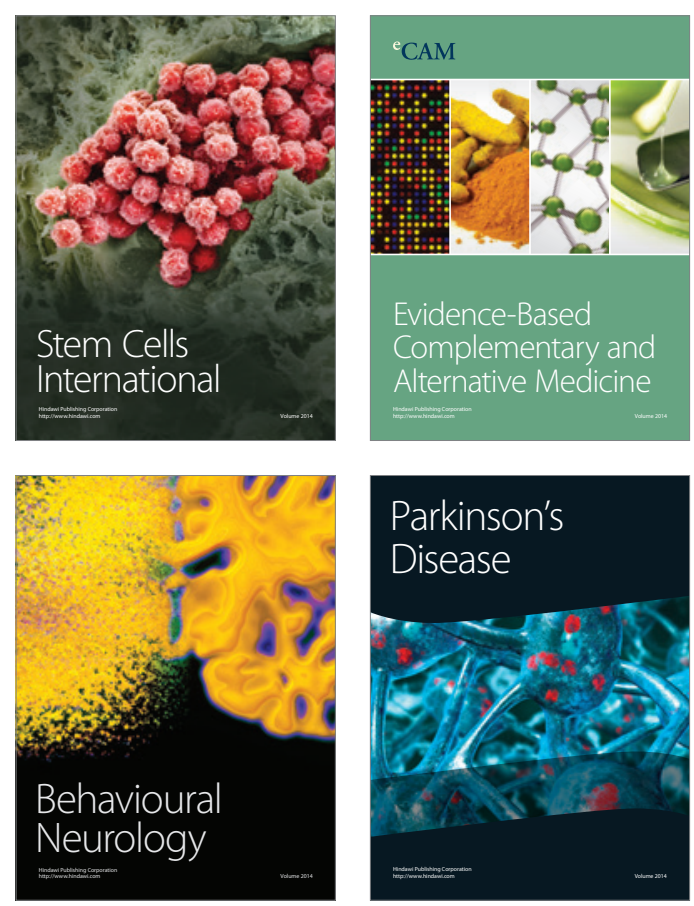

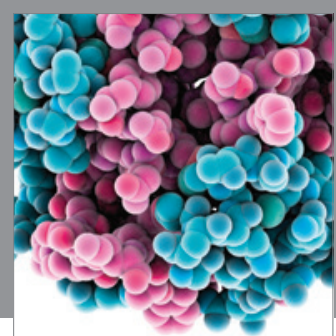

Journal of
Diabetes Research

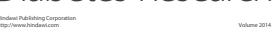

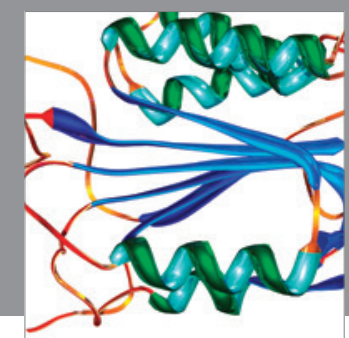

Disease Markers
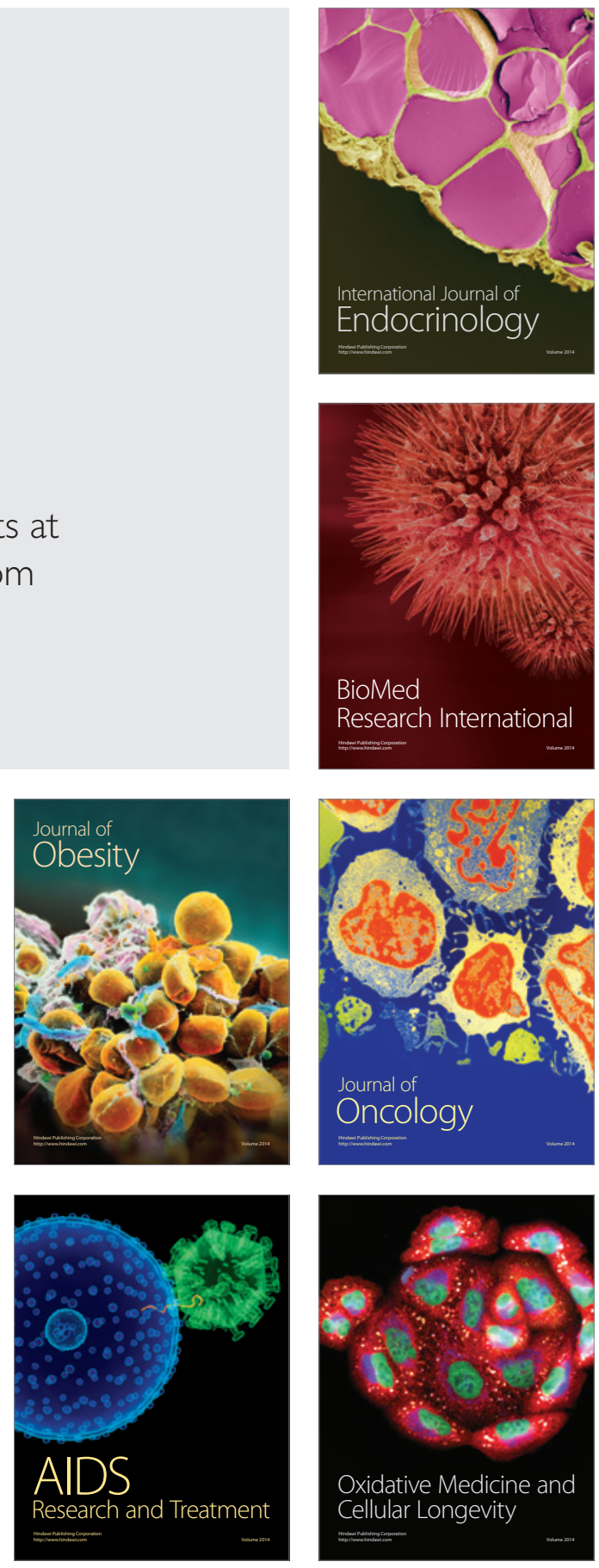